During the first four weeks over two-thirds of the ulcers healed irrespective of the treatment given, and after a further four weeks all except three of the ulcers had healed; the percentage healing in the two groups was almost identical ( $94 \%$ with cimetidine and $89 \%$ with ranitidine). These results were matched in general by prompt symptomatic responses, patients becoming pain free after an average of 13 days with cimetidine and 12 days with ranitidine (table II).

The ulcers ultimately healed in all except three patients, two receiving ranitidine and one cimetidine. Of the patients given ranitidine, one treated early in the trial was given cimetidine for four weeks after only four weeks of ranitidine, but without inducing ulcer healing. The other was given four weeks' treatment with cimetidine after eight weeks with ranitidine, but again without effect.

TABLE III-Mean $( \pm S D)$ concentrations of urea and creatinine with the two drugs

\begin{tabular}{|c|c|c|c|c|c|}
\hline & & & At entry & 2 weeks & 4 weeks \\
\hline $\begin{array}{l}\text { Cimetidine .. } \\
\text { Ranitidine .. }\end{array}$ & $\because$ & $\ddot{x}$ & $\begin{array}{l}\quad \text { Urea }(\mathrm{mmol} / \mathrm{l}) \\
\ldots \quad 4 \cdot 5 \pm 1 \cdot 2 \\
\because \quad 4 \cdot 9 \pm 1 \cdot 3 \\
\text { Creatinine }(u m o l / 1)\end{array}$ & $\begin{array}{l}4 \cdot 8 \pm 0 \cdot 9 \\
5 \cdot 1 \pm 1 \cdot 1\end{array}$ & $\begin{array}{l}4 \cdot 8 \pm 0.9 * \\
4.7 \pm 0 \cdot 9\end{array}$ \\
\hline $\begin{array}{l}\text { Cimetidine .. } \\
\text { Ranitidine .. }\end{array}$ & $\because$ & $\ddot{x}$ & $\begin{array}{l}\quad 89.8 \pm 10.5 \\
\therefore \quad 92.2 \pm 18.0\end{array}$ & $\begin{array}{l}98 \cdot 1 \pm 12 \cdot 0 \dagger \\
89 \cdot 4 \pm 15 \cdot 8\end{array}$ & $\begin{array}{l}95 \cdot 8 \pm 13 \cdot 8 \\
89 \cdot 6 \pm 16.5\end{array}$ \\
\hline
\end{tabular}

Conversion: SI to traditional units-Urea: $1 \mathrm{mmol} / 1 \approx 6 \mathrm{mg} / 100 \mathrm{ml}$. Creatinine: $1 \mu \mathrm{mol} / 1 \approx 0.01 \mathrm{mg} / 100 \mathrm{ml}$.

$*_{\mathrm{t}}=2.2, \mathrm{p}<0.05$

No clinical adverse effects occurred that were attributable to the treatments. In addition there were no significant changes in haematological indices or in serum activity of alkaline phosphatase, transaminase, and $\gamma$-glutamyl transpeptidase or concentrations of calcium, sodium, potassium, and bicarbonate. Serum urea and creatinine con centrations rose slightly but significantly in patients given cimetidine but not in those treated with ranitidine (table III).

\section{Discussion}

The results obtained in this clinical trial show that cimetidine and ranitidine give equivalent results in patients with duodena ulcer. The overall healing rates of about $90 \%$ were equivalent to those we obtained with cimetidine during earlier studies. The difference in clinical responses between $89 \%$ and $94 \%$ for the two treatments is clearly trivial, and if this was a fair sample trebling or quadrupling the total numbers treated would not show any statistically significant difference. Failure of response to ranitidine was matched in the only two patients in whom it occurred by failure of response to cimetidine, again suggesting clinical equivalence in their effects. Choice between the drugs in treating duodenal ulcer is likely to be influenced by their proneness to cause adverse effects rather than by their effect on healing.

We are grateful to Allenbury Glaxo Ltd for supplies of ranitidine, and to Dr D A Ryrie and Dr A M J Woolfson for biochemical and haematological analyses.

\section{Reference}

1 Peden NR, Saunders JHB, Wormsley KG. Inhibition of pentagastrin stimulated and nocturnal gastric secretion by ranitidine. Lancet 1979; ; 690-2.

(Accepted 4 fuly 1980)

\title{
Continuous ambulatory peritoneal dialysis: one year's experience in a UK dialysis unit
}

\author{
R GOKAL， MARY McHUGH， ROSEMARY FRYER， M K WARD， D N S KERR
}

\section{Summary and conclusions}

Thirty-two patients aged 8-63 years trained to manage themselves by continuous ambulatory peritoneal dialysis for end-stage renal failure achieved better steady-state serum biochemistry and much higher haemoglobin and lower serum phosphate concentrations than during treatment with haemodialysis up to one year before. Two patients, however, returned to intermittent haemodialysis because of recurrent peritonitis. Costs of the technique during the first year were less than half those incurred in the first year of home haemodialysis. Nevertheless, the major advantage was the ease with which patient independence and rehabilitation could be achieved.

This technique is an appreciable advance over other forms of management for end-stage renal failure.

\footnotetext{
Department of Medicine, University of Newcastle upon Tyne, Royal Victoria Infirmary, Newcastle upon Tyne NE1 4LP

R GOKAL, MD, MRCP, lecturer in medicine

MARY MCHUGH, MB, MRCP, first assistant (nephrology)

ROSEMARY FRYER, SRN, sister

M K WARD, MB, MRCP, consultant physician

D N S KERR, MSC, FRCP, professor of medicine
}

Nevertheless, until it is more refined and long-term problems have been assessed it should probably be used only in established renal units where back-up treatments are available.

\section{Introduction}

Continuous ambulatory peritoneal dialysis for end-stage renal failure was first described by Popovich et al. ${ }^{1}$ Potential advantages of the technique, however, were offset by an unacceptable incidence of peritonitis and the use of cumbersome glass bottles. ${ }^{2}$ Oreopoulos et al therefore modified the technique by using polyvinylchloride bags, making the procedure simpler and safer. ${ }^{3}$ Subsequently it gained increasing acceptance and is now used worldwide.

The technique requires a peritoneal dialysis solution to be present in the peritoneal cavity continuously except for periods of 20-40 minutes when the patient exchanges the equilibrated solution for fresh solution through a permanent soft indwelling catheter implanted through the anterior abdominal wall into the peritoneal cavity. This differs from "conventional" peritoneal dialysis, in which 2 exchanges of dialysis fluid are performed hourly for 48-72 hours a week. In continuous ambulatory peritoneal dialysis the long dwell times of the dialysis fluid (four to eight hours between exchanges) result in a high degree of 
equilibration of urea, creatinine, and higher molecular-weight solutes between blood and dialysis fluid. These solutes are therefore removed when the fluid is exchanged. Ultrafiltration (fluid removal) is achieved by varying the concentration of glucose in the solution, thus producing an osmotic gradient from blood to dialysis fluid.

In January 1979 the technique was introduced in Newcastle as a definitive method of managing end-stage renal failure. We report our experiences over the first 12 months.

\section{Patients and methods}

Thirty-two patients (16 male, 16 female) aged 8-63 years were managed by the technique for $1-52$ weeks (mean 18.8 weeks), representing 11.5 patient-years of use. Before then 10 of the patients had been managed by intermittent hospital peritoneal dialysis or maintenance haemodialysis. Residual kidney function in all patients varied from 0 to $5 \mathrm{ml} / \mathrm{min}$.

A permanent indwelling Tenchoff peritoneal dialysis catheter was inserted under either general or local anaesthesia. After an initial training period in hospital (mean 13 days) all patients were established at home. The regimen entailed four 21 exchanges of peritoneal dialysis fluid daily -at $0700,1300,1700$, and 2300 (providing dwell times of eight, six, four, and six hours respectively) - the timing of the exchanges being modified occasionally to suit employment or domestic commitments. The dialysis fluid used (Travenol Laboratories Limited) contained sodium $132 \mathrm{mmol}(\mathrm{mEq}) / 1$, calcium $1.75 \mathrm{mmol} / 1$ $(7.0 \mathrm{mg} / 100 \mathrm{ml})$, magnesium $0.75 \mathrm{mmol} / 1(1.8 \mathrm{mg} / 100 \mathrm{ml})$, and lactate $35 \mathrm{mmol} / 1(315 \mathrm{mg} / 100 \mathrm{ml})$. Dextrose concentration was either $75 \mathrm{mmol} / 1(1.36 \mathrm{~g} / 100 \mathrm{ml})$ or $211 \mathrm{mmol} / \mathrm{l}(3.8 \mathrm{~g} / 100 \mathrm{ml})$, producing an osmolarity of 347 or $486 \mathrm{mmol}(\mathrm{mosmol}) / 1$ respectively.

Diet was less restricted than during intermittent haemodialysis and consisted of $80-100 \mathrm{~g}$ protein and $2300-3000 \mathrm{kcal}(9 \cdot 6-12 \cdot 5 \mathrm{MJ})$ daily, only a small restriction being placed on sodium and potassium. Phosphate intake was limited to $1 \cdot 0-1 \cdot 2 \mathrm{~g}$ daily. There was no fluid restriction.

\section{Results}

BIOCHEMICAL

Despite the high protein intake blood urea concentrations were well controlled during treatment (fig 1), mean values ranging between 10 and $20 \mathrm{mmol} / \mathrm{l}(60$ and $120 \mathrm{mg} / 100 \mathrm{ml})$; mean serum creatinine concentration was usually between 800 and $1000 \mu \mathrm{mol} / 1$ ( 9 and 11 $\mathrm{mg} / 100 \mathrm{ml}$ ). Plasma sodium and potassium concentrations were maintained well within the normal range.

Peritoneal protein losses (6-10 g/24 hours, increasing to $12-30 \mathrm{~g} / 24$ hours during episodes of peritonitis) were reflected in the mean serum

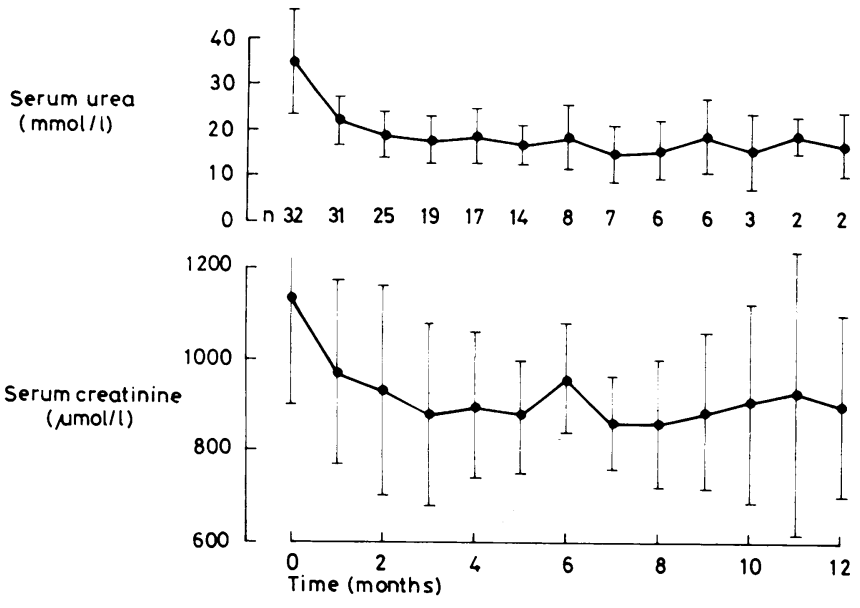

FIG $1-$ Mean serum urea and creatinine concentrations ( $\pm 1 S D)$ in patients treated by continuous ambulatory peritoneal dialysis for up to 12 months. $\mathbf{n}=$ Numbers of patients.

Conversion: SI to traditional units-Serum urea: $1 \mathrm{mmol} / 1 \approx 6 \mathrm{mg} / 100 \mathrm{ml}$. Serum creatinine: $1 \mu \mathrm{mol} / 1 \approx 0.01 \mathrm{mg} / 100 \mathrm{ml}$. albumin and total protein concentrations being in the lower normal range (fig 2). Serum ionised calcium concentrations were within or just below normal (normal range $1 \cdot 15-1 \cdot 3 \mathrm{mmol} / \mathrm{l} ; 4 \cdot 6-5 \cdot 2 \mathrm{mg} / 100$

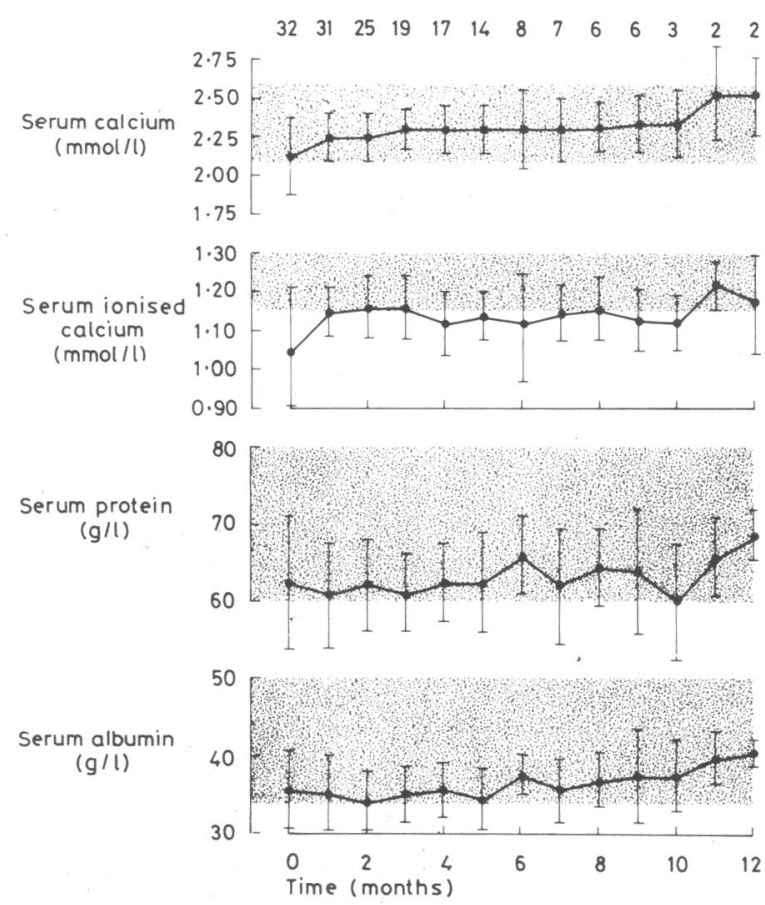

FIG 2-Mean serum calcium, ionised calcium, total protein, and albumin concentrations $( \pm 1 S D)$ in patients receiving continuous ambulatory peritoneal dialysis. Shaded areas represent normal ranges. Numbers of patients shown at each point. Fourteen patients took calcium carbonate supplements $(1.5 \mathrm{~g}$ daily) for initial two to three months. Twelve patients were taking $1 \alpha$-hydroxycholecalciferol or dihydrotachysterol. No aluminium-hydroxidecontaining phosphate binders were used.

Conversion: SI to traditional units-Serum calcium and ionised calcium: $1 \mathrm{mmol} / 1 \approx 4 \mathrm{mg} / 100 \mathrm{ml}$.

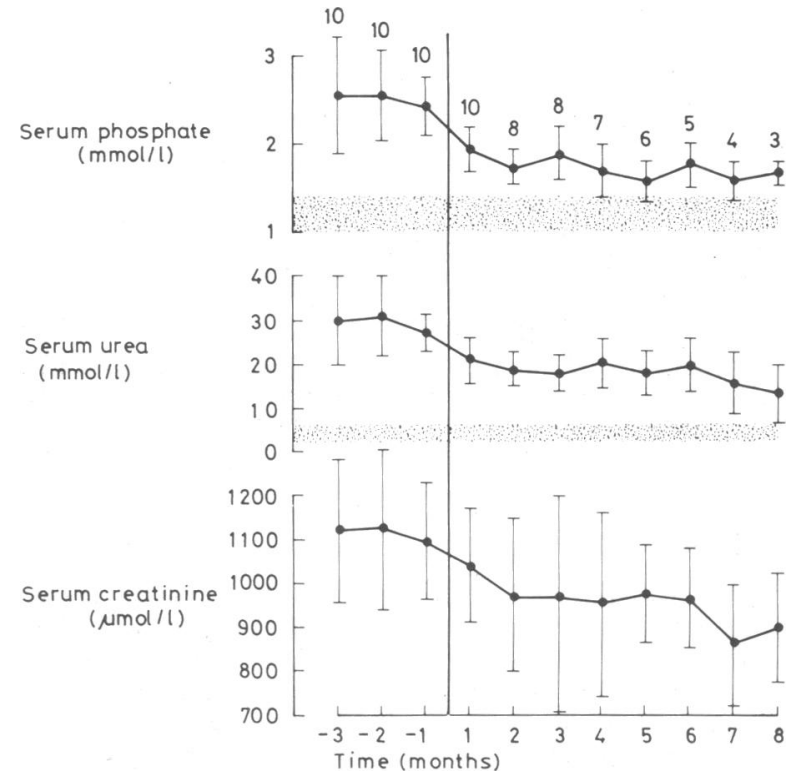

FIG 3-Mean serum phosphate, urea, and creatinine concentrations ( $\pm 1 \mathrm{SD}$ ) in 10 patients three months before starting continuous ambulatory peritoneal dialysis (that is, when receiving maintenance haemodialysis or intermittent peritoneal dialysis) and seven months thereafter. Shaded areas represent normal ranges. Numbers of patients shown at each point. Five patients were taking vitamin $\mathrm{D}$, and four took calcium carbonate supplements for initial two to three months.

Conversion: $S I$ to traditional units-Serum phosphate: $1 \mathrm{mmol} / 1 \approx 3.1 \mathrm{mg} /$ $100 \mathrm{ml}$. Serum urea: $1 \mathrm{mmol} / 1 \approx 6 \mathrm{mg} / 100 \mathrm{ml}$. Serum creatinine: $1 \mu \mathrm{mol} / 1 \approx$ $0.01 \mathrm{mg} / 100 \mathrm{ml}$. 
$\mathrm{ml})$. Serum phosphate concentrations were easier to control than during intermittent peritoneal dialysis or haemodialysis but remained above normal $(0.8-1.4 \mathrm{mmol} / 1 ; 2.5-4.5 \mathrm{mg} / 100 \mathrm{ml}$ ) (fig 3). In comparison the mean serum pre-dialysis phosphate concentration in 18 patients dialysed at home was $2.4 \mathrm{mmol} / 1(7.4 \mathrm{mg} / 100 \mathrm{ml}$ ) (range 1.8 $3 \cdot 0 \mathrm{mmol} / 1 ; 5 \cdot 6-9 \cdot 3 \mathrm{mg} / 100 \mathrm{ml}$.

\section{ANAEMIA}

Mean haemoglobin concentrations increased substantially with treatment and seemed to level off after six to eight months at 10-11 $\mathrm{g} / \mathrm{dl}$ (fig 4); in the 18 patients receiving haemodialysis at home the mean value was $7 \cdot 8 \mathrm{~g} / \mathrm{dl}$ (range $5 \cdot 4-10 \cdot 1 \mathrm{~g} / \mathrm{dl}$ ).

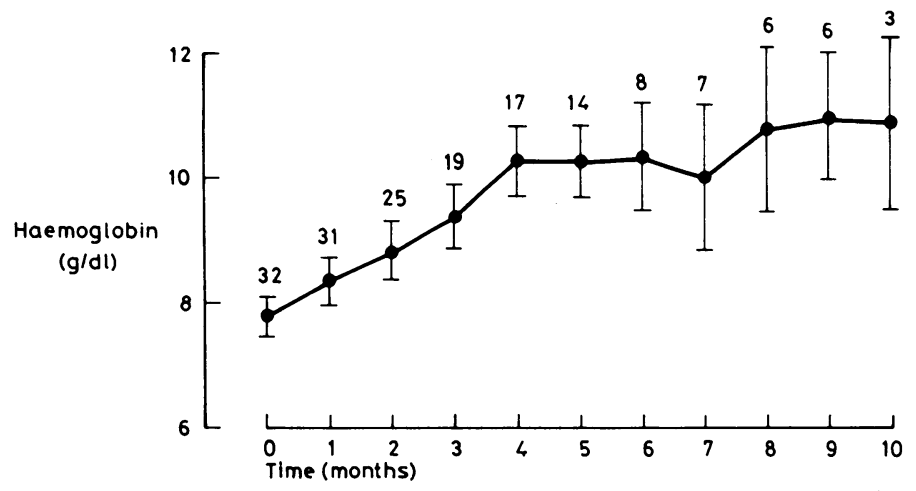

FIG 4-Mean ( \pm SEM) haemoglobin concentrations during first 10 months of treatment. Numbers of patients shown at each point.

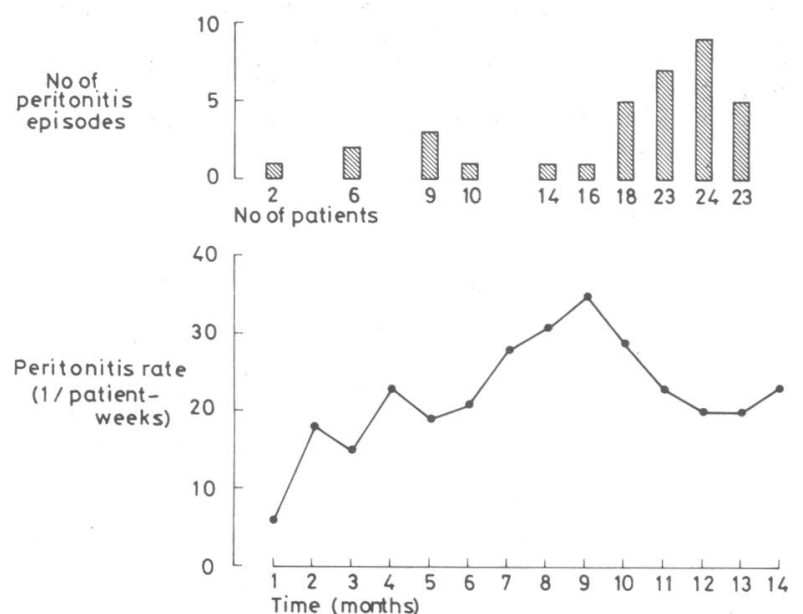

FIG 5-Incidence of peritonitis expressed as episodes/month and in terms of one episode/patient-weeks in relation to months of treatment. At nine months nursing staff and location for conducting outpatient management were changed.

\section{HYPERTENSION}

Of the 32 patients, 16 were taking one to three antihypertensive agents when they began continuous ambulatory peritoneal dialysis. At the time of review seven had become normotensive and no longer needed such treatment, five were taking one agent only, and in four the treatment remained unchanged. None of the patients suffered hypotensive attacks, which are common in American and Canadian series. ${ }^{56}$

\section{PERITONITIS}

Thirty episodes of peritonitis occurred in 16 patients over the 12 months, representing an overall incidence of one episode $/ 20$ patientweeks (fig 5). This incidence resulted from a large number of episodes (21) occurring in the last three months of 1979 , which coincided with a change in nursing staff caring for the patients and the realisation that the busy consulting room attached to the general medical unit was unsuitable for changing the peritoneal dialysis fluid delivery tubing. The infection rate subsequently improved in the first four months of 1980. Ten patients had multiple episodes of peritonitis, and six had single episodes. Five patients accounted for over half of all the episodes. The high sterile peritonitis rate (table I) may have reflected the initial shortcomings of the microbiological culture techniques. For culture, it is important to obtain either a filtrate (about $100 \mathrm{ml}$ ) of the infected peritoneal dialysis fluid or a centrifuged sediment, as the bacterial count may be very low.

TABLE I-Organisms responsible for 30 episodes of peritonitis in 16 patients during treatment for up to 12 months with continuous ambulatory peritoneal dialysis.

$\begin{array}{llllllllll}\text { Staphylococcus aureus } & 4 & \text { Klebsiella } & \ldots & 3 & \text { Pseudomonas } & \ldots & 2 & \\ \text { Staph albus.. } & \ldots & 2 & \text { Enterococci } & \ldots & 2 & \text { Escherichia coli } & \ldots & 1 & \text { Sterile }\end{array}$

In the first nine months peritonitis was managed by reverting to standard manual peritoneal dialysis techniques with "no-dwell" cycles using dialysis fluid containing gentamicin $8 \mathrm{mg} / \mathrm{l}$. From October 1979, however, all episodes of peritonitis were managed by continuing with ambulatory peritoneal dialysis (six cycles daily) and including cefuroxime $200 \mathrm{mg} / 1$ in the dialysis fluid. Eleven of the 16 episodes cleared after 48-72 hours of treatment. In five patient peritonitis recurred four days to three weeks after treatment of the initial episode. In only one was the same organism isolated, so that reinfection was more likely than failure to eradicate the first infection. The Tenchoff catheter had to be removed or reinserted or both on four occasions.

\section{OUTCOME}

Of the 32 patients, four underwent successful kidney transplantation and one, given a cadaver kidney, reverted to continuous ambulatory peritoneal dialysis after nephrectomy for severe rejection. In patients who had episodes of peritonitis while receiving ambulatory peritoneal dialysis transplantation was thought to be more difficult because of increased peritoneal vascularity. Of the five patients who reverted to haemodialysis, only two did so as a result of peritonitis there was a training failure, and another was thought to be having symptoms of inadequate dialysis (this patient was subsequently found to have myeloma). The fifth patient who returned to haemodialysis developed progressive peripheral neuropathy of uncertain aetiology after a failed renal transplant.

Of the 13 female patients continuing with ambulatory peritoneal dialysis, four were working full-time, one was planning to return to work, two were schoolgirls, and six were housewives fully occupied with young families. Of the 10 men, four were working full-time, two were planning to return to work, and two had retired. Two patients remained unemployed because of shortage of jobs.

\section{$\cos T$}

During the study period 18 patients were trained for home haemodialysis and established at home. The high cost of training patients for home haemodialysis in addition to the cost of installation and converting their homes (capital costs including water treatment) are avoided with continuous ambulatory peritoneal dialysis. Owing to the cost of sterile peritoneal dialysis solutions, however, maintenance costs for the two techniques are similar, and the saving is made on capital equipment and early establishment at home (table II).

\section{Discussion}

Our first 12 months show that continuous ambulatory peritoneal dialysis is an extremely acceptable method of treating end-stage renal failure. Most patients reported sustained improvement in wellbeing, which was particularly noticeable in those previously managed by intermittent peritoneal dialysis or haemodialysis. This group was delighted with their new "independence." They commented on the relief of being 
TABLE II-Costs of maintenance haemodialysis at home (18 patients) and continuous ambulatory peritoneal dialysis (32 patients)*

Home haemodialysis

Home conversion:

Installation

Training in renal dialysis

unit

Home dialysis

$$
\text { Total } \cdots \quad \frac{25000}{253000}
$$

Ambulatory peritoneal dialysis

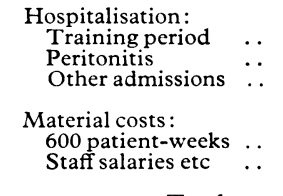

17000 4000 4000

* Based on $\$ 42$ daily for inpatient care and mean training periods in hospital of 13 days and 29 weeks for continuous ambulatory peritoneal dialysis and home haemodialysis respectively.

independent of the machine, their freedom of diet and fluid allowance, and their ability to travel and enjoy holidays.

The technique provides good control of serum biochemistry (fig 3), though a more important advantage may be the inherent steady-state biochemistry achieved compared with the see-saw fluctuation of retained metabolites and fluid balance associated with intermittent peritoneal dialysis and haemodialysis. Though urea clearances were less than during haemodialysis, weekly clearances of higher molecular-weight substances ("middle molecular") may be five times greater than during intermittent haemodialysis. ${ }^{7}$ This may partly explain the increased wellbeing of the patients, if middle molecules are regarded as an important cause of the uraemic syndrome, ${ }^{8}$ and may also account for the better haemoglobin concentrations through efficient removal of erythropoietin inhibitors.

Although it is too early to comment on the long-term effects of calcium-phosphate homoeostasis, serum inorganic phosphate control was apparently better than during intermittent haemodialysis without the use of aluminium-containing phosphatebinding agents. Serum ionised calcium concentration, however, was below normal, whereas total serum calcium was within the normal range. This discrepancy is difficult to explain. Nevertheless, plasma ionised calcium in disease may not have a straightforward relation with total plasma protein, albumin, or $\mathrm{pH} .{ }^{910}$ Calcium supplementation appears to be necessary in these patients and could be achieved by giving calcium carbonate, which may also help phosphate control through its phosphatebinding action. ${ }^{11}$ The necessity for vitamin $\mathrm{D}$ supplementation remains to be established, though the progression of renal osteodystrophy during use of the technique is under study.

Peritonitis remains a major drawback ${ }^{5} 67^{2}$ and is borne out by our findings. All patients with peritonitis were admitted for treatment; however, it may be possible to treat patients on an outpatient basis or institute "self-treatment" with the same antibiotic regimen, admitting only if the peritonitis fails to improve after 48 hours. Our high peritonitis rate reflected a period of three months during which there was a change in nursing staff, and facilities were unsuitable for the number of patients being managed. Our experience suggests that patients receiving continuous ambulatory peritoneal dialysis should be managed by a small group of nursing staff whose major or sole responsibility is for such treatment. Furthermore, outpatient visits and sterile procedures requiring catheter exchange should not be hurried because of inadequate outpatient facilities; an area set aside specifically for these patients is highly desirable. ${ }^{13}$

The major advantages of the technique are the ease with which patient independence and return home may be achieved, the increased sense of wellbeing, the better biochemistry, and cheapness (only in the first year) as compared with home haemodialysis. The only disadvantage is peritonitis, which in our series was readily treatable and did not require prolonged hospital admissions. Great efforts are being made by many major manufacturers to improve connections, so that safety and sterility need no longer depend on the patient's obsession with a sterile technique.

Continuous ambulatory peritoneal dialysis offers exciting possibilities for the management of end-stage renal failure.
Some $27 \%$ of all our patients in Newcastle receiving dialysis are being managed by the technique, and eventually the proportion will probably be increased. Nevertheless, until the technique is more refined and long-term problems are assessed it should probably be confined to established renal units where back-up with other forms of treatment is available.

We are indebted to Travenol Laboratories Limited (UK) for financial support for Sister Fryer. We also thank Dr R Wilkinson and Dr R W Elliott for referring patients, and Mr R M R Taylor and his surgical colleagues for inserting the Tenchoff long-dwelling peritoneal catheters.

\section{References}

1 Popovich RP, Moncrief JW, Decherd JF, Bomar JB, Pyle WK. The definition of a novel portable/wearable equilibrium peritoneal dialysis technique. Abstracts; American Society for Artificial Internal Organs $1976 ; 5: 64$.

2 Popovich RP, Moncrief JW, Nolph KD, Ghods AJ, Twardonski ZT, Pyle WK. Continuous ambulatory peritoneal dialysis. Ann Intern Med $1978 ; 88: 449-56$.

${ }^{3}$ Oreopoulos DG, Robson M, Izatt S, Clayton S, De Veber GA. A simple and safe technique for continuous ambulatory peritoneal dialysis (CAPD). Trans Am Soc Artif Intern Organs 1978;24:484.

4 Oreopoulos DG. The coming of age of continuous ambulatory peritoneal dialysis (CAPD). Dialysis and Transplantation 1979;8:460-2.

${ }^{5}$ Oreopoulos DG, Clayton S, Dombros N, Zellerman G, Katirtzoglou A. Experience with continuous ambulatory peritoneal dialysis (CAPD). Trans Am Soc Artif Intern Organs 1979;25:95-9.

${ }^{6}$ Moncrief JW. Continuous ambulatory peritoneal dialysis. Dialysis and Transplantation $1979 ; 8: 1077-80$.

7 Oreopoulos DG, Robson M, Faller B, Ogilvie R, Rapoport A, De Veber GA. Continuous ambulatory peritoneal dialysis: a new era in the treatment of chronic renal failure. Clin Nephrol 1979;11:125-8.

${ }^{8}$ Knochel JP, Seldin DW. The pathophysiology of uraemia. In: Brenner BM, Rector FC, eds. The kidney. Philadelphia: WB Saunders, 1976: 1452-3.

${ }^{9}$ Ladenson JH, Lewis JW, Boyd JC. Failure of total calcium corrected for protein, albumin and $\mathrm{pH}$ to correctly assess free calcium. $\mathcal{f}$ Clin Endocrinol Metab 1978;46:986-93.

10 Conceicao SC, Weightman D, Smith PA, Luno J, Ward MK, Kerr DNS. Serum ionised calcium concentration measurement versus calculation. Br Med f 1978; :1103-5.

11 Gokal R, Fryer R, McHugh M, Ward MK, Kerr DNS. Calcium and phosphate control in continuous ambulatory peritoneal dialysis. In: Legrain, ed. Continuous ambulatory peritoneal dialysis. Amsterdam: Excerpta Medica, 1980:283-91.

12 Fenton SA, Cattram DC, Allen A, et al. Initial experiences with continuous ambulatory peritoneal dialysis. Artificial Organs $1979 ; 3: 206-9$.

13 Oreopoulos DG. Requirements for the organisation of a continuous ambulatory peritoneal dialysis programme. Nephron $1979 ; 24: 261$-3.

(Accepted 12 fune 1980)

ONE HUNDRED YEARS AGO A case tried at Chester this week shows that the arm of the law is not long enough or strong enough to deal effectually with the "baby-farmers," A woman was charged with cruelly ill-treating a female child placed in her charge, by neglecting to provide it with sufficient food. The child had been handed over to the prisoner by its mother, a domestic servant, with the sum of $£ 5$. It was found in November last by an inspector of police, lying in a basket in front of a fire, in a horribly emaciated condition. Although eighteen months old, it weighed only eight pounds two ounces, the weight of a newly born child. This was not surprising, for it came out in the evidence that the only nourishment it was allowed was some skimmed milk twice a day, at morning and night. "It had nothing but the dry bottle to suck at all day." There was a question as to whether it had not some inherited disease, and the woman was therefore only charged with criminal neglect. The jury found her guilty, and the judge sentenced her to six months' hard labour, observing that "this was a terrible offence which the law relating to manslaughter had probably not contemplated. It was becoming a common vice and crime that persons who had illegitimate children got rid of them to those who had no natural affection, and who neglected them and caused their death. He could not punish the prisoner for manslaughter." Yet to give a sickly infant no food but a little skimmed milk twice a day is a sure method of killing it, and really seems more like wilful murder than manslaughter. (British Medical fournal, 1880.) 